University of Warwick institutional repository: http://go.warwick.ac.uk/wrap This paper is made available online in accordance with publisher policies. Please scroll down to view the document itself. Please refer to the repository record for this item and our policy information available from the repository home page for further information.

To see the final version of this paper please visit the publisher's website. Access to the published version may require a subscription.

Author(s): Stephen Broadberry and Carsten Burhop

Article Title: Comparative Productivity in British and German Manufacturing Before World War II: Reconciling Direct Benchmark Estimates and Time Series Projections

Year of publication: 2007

Link to published version: http://dx.doi.org/

10.1017/S0022050707000125

Publisher statement: None 


\section{Comparative Productivity in British and German Manufacturing Before World War II: Reconciling Direct Benchmark Estimates and Time Series Projections}

\section{STEPHEN BROADBERRY AND CARSTEN BURHOP}

This article provides a new benchmark estimate of comparative Germany/U.K. labor productivity in manufacturing for circa 1907, and experiments with alternative German manufacturing production indices for time series projection from a circa 1935 benchmark. A consistent picture of broadly similar levels of manufacturing labor productivity in Britain and Germany throughout the period 1871-1938 is established. We also show that a substantial German productivity lead had already emerged in heavy industry by 1907 , but was offset by a substantial British productivity lead in light industry. For the pre-1914 period, an additional check is provided using nominal income-based estimates.

Controversy continues to surround the issue of Germany's level of labor productivity in manufacturing compared with that of Britain before World War II. A long tradition going back at least as far as Ernest Williams has suggested that Britain was already falling behind Germany in manufacturing in the late nineteenth century, and this view was bolstered by the views of Alexander Gerschenkron and David Landes, who saw Germany as modernizing before World War I on the basis of heavy industry. ${ }^{1}$ Worries about competition from Germany resurfaced during the interwar period, which saw Germany reclaim its position in export markets. Furthermore, this view of Germany leapfrogging ahead of Britain also underpins Alfred D. Chandler Jr.'s characterization of German manufacturing as closer to the successful U.S. model of "managerial capitalism" than the supposedly failing British model of "personal capitalism."2

The Journal of Economic History, Vol. 67, No. 2 (June 2007). (C) The Economic History Association. All rights reserved. ISSN 0022-0507.

Stephen Broadberry is Professor, Department of Economics, University of Warwick, Coventry CV4 7AL, United Kingdom and Co-ordinator of the Economic History Initiative at the Centre for Economic Policy Research, London. E-mail: S.N.Broadberry@warwick.ac.uk. Carsten Burhop is Heisenberg-Fellow, Max-Planck-Institute for Research on Collective Goods, KurtSchumacher-Strasse 10, 53113 Bonn, Germany. E-mail: burhop@coll.mpg.de.

We would like to thank participants in the Berlin Colloquium, the Second Conference on German Cliometrics, and the referees for helpful comments. Remaining errors are our responsibility. The financial support of the European Commission Marie Curie Actions, (Contract no. MRTN-CT-2004-512439) as well as the support of Juliane Schrader is gratefully acknowledged.

${ }^{1}$ Williams, Made in Germany; Gerschenkron, Economic Backwardness; and Landes, Unbound Prometheus.

${ }^{2}$ Chandler, Scale and Scope. 
However, this traditional view has proved difficult to square with work in the historical national accounts (HNA) framework. In a series of studies working at the level of the aggregate economy, Angus Maddison showed that GDP per hour worked and GDP per employee were substantially higher in Britain than in Germany before World War II, projecting with times series from a benchmark close to the present. ${ }^{3}$ Furthermore, Rainer Fremdling pointed out that the sectoral data underpinning the Maddison results also show labor productivity in industry to have been substantially lower in Germany than in Britain before World War I. ${ }^{4}$ Fremdling's study used data on nominal income in the commodity-producing sectors of the two countries in particular years, converted at purchasing power parities (PPPs) derived from agricultural and industrial products. Strictly speaking, Fremdling's results apply to a wide definition of industry, which includes construction and the utilities as well as manufacturing, but manufacturing was by far the biggest industrial sector in both countries. Recognizing the disjuncture between this result and the traditional literature, Fremdling records his doubts about Germany having lower industrial productivity than Britain on the eve of World War I and speculates that it may reflect an under-estimation of capital income in Germany by Walther Hoffmann. ${ }^{5}$

By projecting with the time series of Charles Feinstein and Hoffmann from a benchmark for circa 1935 produced by Broadberry and Fremdling, Broadberry then showed that labor productivity in manufacturing was slightly higher in Germany than in Britain in the pre-World War I period. ${ }^{6}$ This work, which is perhaps best seen as taking an intermediate position between the traditional view of a large German superiority and the revisionist view of higher British productivity, has in turn been called into question by challenges to the Hoffmann index of industrial production and to the original Broadberry and Fremdling benchmark for circa 1935. ${ }^{7}$ Criticism of the Hoffmann industrial production index has come from Albrecht Ritschl and Burhop and Guntram Wolff, while doubt has been cast on the Broadberry/Fremdling benchmark by Fremdling and Reiner Stäglin's discovery of deliberate falsification of the records by officials to conceal the production of munitions by the Nazi regime. ${ }^{8}$

\footnotetext{
${ }^{3}$ Maddison, Phases, Dynamic Forces, Monitoring, and World Economy.

${ }^{4}$ Fremdling, "Productivity Comparison."

${ }^{5}$ Ibid., pp. 39-42; and Hoffmann, Das Wachstum.

${ }^{6}$ Feinstein, National Income; Hoffmann, Das Wachstum; Broadberry and Fremdling, "Comparative Productivity"; and Broadberry, "Manufacturing."

${ }^{7}$ Hoffmann, Das Wachstum; and Broadberry and Fremdling, "Comparative Productivity."

${ }^{8}$ Hoffmann, Das Wachstum; Ritschl, "Spurious Growth"; Burhop and Wolff, "Compromise Estimate"; Broadberry and Fremdling, "Comparative Productivity"; and Fremdling and Stäglin, "Die Industrieerhebung."
} 
It would therefore be very helpful to have a benchmark estimate of the comparative Germany/U.K. labor productivity level in manufacturing for the pre-World War I period that is entirely independent of the HNA time series data. The first objective of this article is to provide such an estimate, based on the British industrial census for 1907 and official German data for a number of industries in 1907/08. As well as establishing more firmly the aggregate picture of broadly equal labor productivity in the pre-World War I period, this new benchmark provides for the first time disaggregated estimates of comparative labor productivity in different branches of industry for the pre-World War I period. The sectoral picture suggests that a substantial German labor productivity lead in heavy industry (chemicals, metals) was offset by a substantial British labor productivity lead in light industry (textiles and food, drink and tobacco). In addition, Britain had a labor productivity advantage in mining, an important nonmanufacturing industry.

A second objective is to experiment with alternative indices of German manufacturing output, to check for the consistency between time series projections and direct benchmark estimates. The two benchmarks for circa 1907 and circa 1935 are broadly consistent with the time series projections based on the Hoffmann index for Germany. A new series of Burhop and Wolff for the pre-World War I era can be incorporated in a way that is consistent with the two benchmarks, but suggests a somewhat larger German labor productivity lead between the 1870s and the 1890s than suggested by the Hoffmann series. ${ }^{9}$ A problem of inconsistency arises only in the case of Ritschl's new index of German industrial production for the interwar period, which incorporates a very major change to the output of the metal-working sector for the years $1925-1938 .{ }^{10}$

A third objective is to rework Fremdling's income-based estimates of comparative Germany/U.K. industrial labor productivity, based on nominal net income per employee in British and German industry, converted at PPPs for agricultural and industrial products and converted at market rates. ${ }^{11}$ We incorporate Burhop and Wolff's allowance for Hoffmann's underestimation of capital income in the pre-1914 period, restrict our attention to manufacturing and apply PPPs based only on manufactured products to these new data. ${ }^{12}$ We find broadly equal levels of manufacturing labor productivity in the two countries throughout the period 1875-1913, as suggested by the output-based estimates. Overall, then, we are able to reconcile most of the existing time series

\footnotetext{
${ }^{9}$ Burhop and Wolff, "Compromise Estimate"; and Hoffmann, Das Wachstum.

${ }^{10}$ Ritschl, "Spurious Growth."

${ }^{11}$ Fremdling, "Productivity Comparison."

12 Burhop and Wolff, "Compromise Estimate"; and Hoffmann, Das Wachstum.
} 
and benchmark estimates of comparative Germany/U.K. labor productivity in manufacturing before World War II.

\section{A BENCHMARK FOR CIRCA 1907}

\section{Data Sources}

Although there was no full industrial census for Germany before World War I, much high quality information was collected. Some of this information was published in the form of a complete employment census for 1907, while for a number of industries, further information on the quantity and value of output and material inputs appeared in various sources. The Imperial Office of the Interior (Reichsamt des Inneren) started industry surveys regarding output (value and volume), input (value and volume), employment, and wages for some industries already in 1897. After the turn of the century, such surveys were conducted several times and for some industries on an annual basis. The findings were finally published by the Imperial Statistical Office. ${ }^{13}$ Furthermore, production taxes for beer, sugar, and tobacco were levied in Germany, making collection of output data necessary. These output data were published annually by the Imperial Statistical Office and could be matched with employment data from the 1907 employment census.

In contrast to the British census of production, Germany's statistical office did not strictly apply the concept of value added. The modern national accounting standards use the term "gross value added" as the value of output less the value of intermediate goods consumed in the production process. The British census of 1907 used the term net output instead of gross value added. The German term Nettoproduktionswert basically corresponds to the modern concept of gross value added, but because the Imperial Office of the Interior did not collect comprehensive data on intermediate goods consumed, this measure is likely to be biased. ${ }^{14}$

Nevertheless, this industrial census is a very useful source, covering nearly all firms in the surveyed industries. All firms listed by trade associations (Berufsgenossenschaften) were asked to submit anonymously information about the type of business, the number of establishments, the number of employees, the wage bill, the volume and value of intermediate goods consumed, and the volume and value of production and of goods sold. ${ }^{15}$ Inputs were valued inclusive of transportation costs to

\footnotetext{
${ }^{13}$ Kaiserliches Statistisches Amt, "Ergebnisse"; and "Die Ergebnisse."

14 Tooze, Statistics, pp. 56-57.

${ }^{15}$ All employees of the firms listed by the Berufsgenossenschaften were counted for the industrial census, not only the insured employees.
} 
the factory, whereas outputs were valued at factory gate prices (without transport costs). However, for all industries, no information was collected on several items of intermediate consumption. In particular, the costs of maintenance of machinery and buildings, heating and power generation, packaging and overheads are not included in the German data throughout. Therefore, comparing German Nettoproduktionswerte with British net output might overstate German labor productivity. The German census data are also less comprehensive in terms of industries covered than the British data. Whereas the British data cover total manufacturing, the German data focus on selected industries (see Appendix 1 for details). Furthermore, we can only use German and British data if we find the same information for the same industries in both censuses. The German data included in our 1907 benchmark cover more than 1.7 million employees, slightly more than 29 percent of Germany's total manufacturing employment in that year. The British data used for our benchmark include circa 1.56 million employees, about 27 percent of total manufacturing employment.

In our judgment, these sources are sufficient to allow us to make reasonably reliable estimates of physical output per worker in Germany in $1907 / 08$, along the lines of those produced for $1935 / 36$ by Laszlo Rostas and reworked by Broadberry and Fremdling. ${ }^{16}$ These estimates can then be compared with estimates of physical output per worker in the United Kingdom, derived from the First Census of Production for 1907, which provide a comprehensive overview of British industrial performance. ${ }^{17}$

\section{Weighting Scheme}

Although it is possible to estimate net output for some German industries, we do not have sufficient information to do this reliably for the whole manufacturing sector. Hence for Germany, we are forced to rely on employment weights, shown here in Table 1. For the United Kingdom, we have both employment and net output weights, which are also shown in Table 1. We shall see, using U.K. data, that the choice of net output or employment weights makes little difference, so that the lack of German net output weights is unlikely to be too serious a problem.

The structure of industry was quite different in the two countries, with German manufacturing more oriented towards heavy industry, particularly metal production, and British manufacturing more oriented

\footnotetext{
${ }^{16}$ Rostas, Comparative Productivity; and Broadberry and Fremdling, "Comparative Productivity."

${ }^{17}$ Board of Trade, Final Report.
} 
TABLE 1

EMPLOYMENT AND NET OUTPUT WEIGHTS IN 1907, GERMANY AND UNITED KINGDOM

\begin{tabular}{|c|c|c|c|}
\hline & $\begin{array}{l}\text { German } \\
\text { Employment } \\
\text { Weights }\end{array}$ & $\begin{array}{c}\text { U.K. } \\
\text { Employment } \\
\text { Weights }\end{array}$ & $\begin{array}{l}\text { U.K. } \\
\text { Net Output } \\
\text { Weights }\end{array}$ \\
\hline \multicolumn{4}{|c|}{ A. Manufacturing } \\
\hline General chemicals & 0.18 & 0.92 & 0.88 \\
\hline Coke & 0.82 & 0.08 & 0.12 \\
\hline CHEMICALS \& ALLIED & 3.27 & 2.44 & 4.47 \\
\hline Iron \& steel & 0.78 & 0.72 & 0.72 \\
\hline Nonferrous metals & 0.20 & 0.19 & 0.19 \\
\hline Motor vehicles & 0.02 & 0.09 & 0.09 \\
\hline METALS \& ENGINEERING & 39.33 & 29.08 & 30.01 \\
\hline Cotton & 0.72 & 0.83 & 0.81 \\
\hline Silk & 0.18 & 0.05 & 0.03 \\
\hline Leather & 0.10 & 0.12 & 0.16 \\
\hline TEXTILES \& CLOTHING & 22.49 & 36.82 & 27.40 \\
\hline Brewing & 0.50 & 0.66 & 0.81 \\
\hline Tobacco & 0.28 & 0.29 & 0.12 \\
\hline Sugar & 0.22 & 0.05 & 0.07 \\
\hline FOOD, DRINK, \& TOBACCO & 21.53 & 8.15 & 16.29 \\
\hline Cement & 1.00 & 1.00 & 1.00 \\
\hline OTHER MANUFACTURING & 13.38 & 23.50 & 21.83 \\
\hline TOTAL MANUFACTURING & 100.00 & 100.00 & 100.00 \\
\hline \multicolumn{4}{|c|}{ B. Industry } \\
\hline MANUFACTURING & 90.26 & 85.63 & 82.51 \\
\hline Salt mining & 0.04 & 0.01 & 0.01 \\
\hline Coal mining & 0.83 & 0.97 & 0.97 \\
\hline Iron ore mining & 0.13 & 0.02 & 0.02 \\
\hline MINING & 9.74 & 14.37 & 17.49 \\
\hline TOTAL INDUSTRY & 100.0 & 100.0 & 100.0 \\
\hline
\end{tabular}

Source: Board of Trade, Final Report; and Kaiserliches Statistisches Amt, "Berufs- und Betriebszählung."

towards light industry, particularly textiles and clothing. However, note that although Britain had quite a large share of net output in food, drink, and tobacco, this accounted for a smaller share of employment, because of high net output per worker. Britain also had a substantially larger share of the labor force in mining than did Germany.

The weighting scheme in Table 1 is derived in the following way. First, employment (and also net output for Britain) was allocated across major sectors (indicated in upper case letters) from census sources. ${ }^{18}$ Second, within major sectors, shares were allocated in proportion to the sectors for which we were able to make matches. For example, focusing on German employment weights, the major sector Chemicals \& Allied Industries accounted for 188,073 employees out of a total of 5,758,891

${ }^{18}$ Ibid.; and Kaiserliches Statistisches Amt, "Berufs- und Betriebszählung." 


\begin{tabular}{lc}
\hline \hline & Germany/United Kingdom \\
\hline General chemicals & 126.6 \\
Coke & 98.9 \\
CHEMICALS \& ALLIED & 113.9 \\
Iron \& steel & 137.8 \\
Nonferrous metals & 157.9 \\
Motor vehicles & 89.7 \\
METALS \& ENGINEERING & 139.2 \\
Cotton & 85.6 \\
Silk & 74.9 \\
Leather & 67.8 \\
TEXTILES \& CLOTHING & 82.3 \\
Brewing & 90.5 \\
Tobacco & 28.3 \\
Sugar & 47.3 \\
FOOD, DRINK, \& TOBACCO & 66.9 \\
Cement & 108.1 \\
OTHER MANUFACTURING & 108.1 \\
TOTAL MANUFACTURING & 105.0 \\
& \\
Salt mining & 57.8 \\
Coal mining & 78.5 \\
Iron ore mining & 91.0 \\
MINING & 78.7 \\
TOTAL INDUSTRY & 101.8 \\
\hline
\end{tabular}

Source: See Appendix 1.

in manufacturing, or 3.27 percent. Within this major sector, we were able to match data on two industries, general chemicals and coke. The general chemicals firms surveyed employed 4,578 persons, whereas in coke production 20,504 persons were employed in the surveyed firms. Total employment in the surveyed firms was thus 25,082 , resulting in an employment weight of 82 percent for coke and 18 percent for general chemicals. Part A of Table 1 provides the weights within manufacturing, and part B provides the weights for industry including mining.

\section{Results}

The individual industry results reported in Table 2 are based mainly on comparisons of physical output per worker in the two countries, with a value above 100 indicating a German productivity advantage and a value below 100 indicating a British productivity advantage. The single figure for each sector is arrived at by taking the geometric mean of results using German and British employment weights. The figure for to- 
tal manufacturing is 105.0 , which is the geometric mean of 105.5 using German employment weights and 104.6 using British employment weights. Note that using British net output weights makes no real difference, yielding a comparative productivity ratio of 104.5. For total industry the geometric mean of 101.8 is derived from 102.9 using German employment weights and 100.8 using British employment weights, whereas the use of British net output weights yields a figure of 100.0.

One might argue that these comparative labor productivity measures are biased because the British data are for 1907 throughout, whereas German data are for 1907 (motor vehicles, cotton, silk, brewing, tobacco, sugar), 1908 (chemicals, coke, iron \& steel, nonferrous metals, mining), and 1910 (leather, cement) respectively. Taking employment weights, 28 percent of the German data are for 1907, 68 percent for 1908, and 4 percent for 1910. Between 1907 and 1908 (1910) labor productivity increased faster in Germany than in Britain, thus our benchmark might overstate German productivity leadership. If projections are based on Hoffmann's classic figures, comparative labor productivity improved in favor of Germany between 1907 and 1908 (1910) by 8.2 percent (14.7 percent).$^{19}$ Weighting this productivity increase by the employment shares for the different years yields a possible overestimation of Germany's productivity lead of 6.2 percent. Reducing our comparative labor productivity estimate by this leads to comparative labor productivity in manufacturing for 1907 of 98.9. Thus, even accounting for different years of census data did not change the basic results of a roughly equal labor productivity in manufacturing before World War I.

Just as important as the results for total manufacturing and total industry is the distribution of comparative productivity ratios across major sectors. The key finding here is that Germany had higher labor productivity in heavy manufacturing, particularly in ferrous and nonferrous metals, but also in chemicals, while Britain had higher productivity in light manufacturing, particularly textiles and clothing and food, drink, and tobacco. Britain also had a productivity advantage at this time in mining.

TIME SERIES PROJECTION, 1871-1938

\section{Methodological Considerations}

Benchmarks are available only for a small number of years. To build up a full picture of the evolution of comparative productivity over time, it is necessary to use time series to project forwards and backwards.

\footnotetext{
${ }^{19}$ Hoffmann, Das Wachstum.
} 
However, this inevitably raises potential index number problems because of variation in the weighting schemes used in the output time series for the two countries, and differences in the proportion of output covered between the two benchmarks for each country. This has led to some controversy since the work of the Income Comparisons Project (ICP) for the post-1950 period, with H. Krijnse Locker and M. D. Faerber providing an early statement of the problem. ${ }^{20}$

Having initially provided a set of benchmarks that conflicted with time series projections, Alan Heston, Robert Summers and Bettina Aten have acknowledged that this is unsatisfactory in the following terms:

If per capita G.D.P. in India relative to Korea is $40 \%$ in a 1970 benchmark and $35 \%$ in a 1975 benchmark, then one inference is that the growth rate per capita in Korea must have been about 5\% more than in India between 1970 and 1975. Often such an implied result is not consistent with the national growth rates in the two countries, posing a problem to users. ${ }^{21}$

One solution offered by Summers and Heston to the problem of inconsistency between benchmarks and time series projections was to change the national growth rates as well as the benchmarks, in a process known as "consistentization." 22 However, Heston, Summers, and Aten have now acknowledged that it is difficult to persuade people of the need to change widely accepted growth rates to fit in with benchmark estimates:

It was hard to sell the idea of modifying country growth rates to countries, international organizations and to men or women of affairs. Therefore in our recent uses of consistentization we have not modified country growth rates, but only the different benchmark estimates. ${ }^{23}$

The methodology adopted by Broadberry has been to recognize the need to tell a coherent story, but at the same time, to acknowledge the inevitability of some disagreement between constant price time series projections and current price benchmark estimates. ${ }^{24}$ If a projection is made from a single benchmark, other benchmarks can be used to provide a cross-check on the projection, with Broadberry suggesting that a reasonable aim should be to keep disagreements between direct benchmarks and time series projections to within 10 percent. ${ }^{25}$

\footnotetext{
${ }^{20}$ Krijnse Locker and Faerber, "Space and Time."

${ }^{21}$ Heston, Summers and Aten, "Price Structures," p. 2.

${ }^{22}$ Summers and Heston, "New Set."

${ }^{23}$ Heston, Summers and Aten, "Price Structures," p. 6.

${ }^{24}$ Broadberry, "Manufacturing," "How Did the United States?" and "Relative Per Capita Income"; Krijnse Locker and Faerber, "Space and Time"; Nuxoll, "Differences"; and Dowrick and Akmal, "Contradictory Trends."

${ }^{25}$ Broadberry, "Manufacturing."
} 
Applying this to the case of the United States and the United Kingdom during the period 1870-1990, Broadberry was critical of Marianne Ward and John Devereux's claim, on the basis of a new benchmark, that U.S. per capita income in 1872 was 18 percent higher than in the United Kingdom, compared with Maddison's result, based on time series projection, that the United States was at 78 percent of the U.K. level, a discrepancy of 40 percentage points, or more than 50 percent of the Maddison estimate. ${ }^{26}$ Broadberry's case was strengthened by the provision of additional economy-wide benchmarks for 1910, 1937, and 1950, plus reconciliation of benchmarks and time series projections at the level of ten subsectors, at the previously mentioned dates plus additional benchmarks for the majority of sectors at $1924,1930,1968$, and $1990 .{ }^{27} \mathrm{In}$ most cases, benchmarks fell within 10 percent of the time series projections. Given the widespread acceptance of the time series produced by Feinstein and by John Kendrick, together with the coherence between these times series and the benchmarks, there must be a strong presumption in favor of the Maddison estimates. ${ }^{28}$ We now consider the reconciliation of time series projections and direct benchmarks in the case of German and British manufacturing industry.

\section{Choice of Benchmark}

The first issue that must be decided is the choice of benchmark on which to base the time series projections. As we have constructed a new benchmark for 1907, this obviously provides one option for the base. However, we could alternatively use either the Broadberry and Fremdling benchmark for 1935 or the Fremdling, Herman de Jong and Marcel Timmer benchmark for $1935 / 36 .^{29}$ The latter draws on the findings of Fremdling and Stäglin, that the published 1936 census was distorted for military-strategic purposes. ${ }^{30}$ Fremdling and Stäglin recalculate the input-output table for 1936, using archival records. This leads to different estimates of net output and employment in individual branches of industry, although the effects on industry as a whole are quite small. We have opted for the 1935 benchmark of Broadberry and Fremdling for

\footnotetext{
${ }^{26}$ Broadberry, "Relative Per Capita Income"; Ward and Devereux, "Measuring British Decline"; and Maddison, Monitoring.

${ }^{27}$ Broadberry, "How Did the United States?"

${ }^{28}$ Feinstein, National Income; Kendrick, Productivity Trends; and Maddison, Monitoring.

${ }^{29}$ Broadberry and Fremdling, "Comparative Productivity"; and Fremdling, de Jong and Timmer, "British and German Manufacturing."

${ }^{30}$ Fremdling and Stäglin, "Die Industrieerhebung" and "Eine Input-Output-Tabelle"; and Reichsamt für wehrwirtschaftliche Planung, Die deutsche Industrie.
} 
TABLE 3

COMPARATIVE GERMANY/UNITED KINGDOM LABOR PRODUCTIVITY, CIRCA 1935

(United Kingdom $=100)$

A. Broadberry and Fremdling

\begin{tabular}{lc}
\hline & Germany/United Kingdom \\
\cline { 2 - 2 } Chemicals \& allied & 123 \\
Metal production & 116 \\
Engineering & 120 \\
Textiles \& clothing & 97 \\
Food, drink, \& tobacco & 41 \\
Other manufacturing & 102 \\
Total manufacturing & 102 \\
& B. Fremdling, de Jong and Timmer \\
\hline
\end{tabular}

\begin{tabular}{lcc}
\hline & \multicolumn{2}{c}{ Germany/United Kingdom } \\
\cline { 2 - 2 } & Single-Deflated & Double-Deflated \\
\cline { 2 - 2 } Chemicals & 111 & 126 \\
Iron \& steel & 134 & 175 \\
Nonferrous metals & 133 & 104 \\
Engineering & 112 & 106 \\
Textiles & 97 & 76 \\
Leather & 73 & 47 \\
Clothing & 94 & 93 \\
Food & 69 & 78 \\
Building materials & 98 & 106 \\
Paper & 103 & 141 \\
Timber & 151 & 90 \\
Miscellaneous & 100 & 95 \\
Total manufacturing & 105 & 107 \\
\hline Sources: Derived from
\end{tabular}

Sources: Derived from Broadbery and Fremdling, "Comparative Productivity"; and Fremdling, de Jong, and Timmer, "British and German Manufacturing."

the following reasons. ${ }^{31}$ First, there is much less information available for 1907 than for 1935/36, so a later benchmark is likely to be more reliable. Second, the Broadberry and Fremdling benchmark is on the same conceptual basis as the 1907 benchmark presented in this article, working in terms of quantity indicators rather than nominal net output compared using industry-specific price ratios.

A comparison between the Broadberry and Fremdling and the Fremdling, de Jong, and Timmer benchmarks for circa 1935 is provided in parts A and B of Table 3. Reassuringly, there is a strong measure of agreement amongst the different benchmarks, despite the conceptual differences and the distortions introduced by military planners. First, note the narrow range for the total manufacturing comparative produc-

${ }^{31}$ Broadberry and Fremdling, "Comparative Productivity." 
tivity ratio in the different studies, with Fremdling, de Jong, and Timmer arriving at a ratio of 105 or 107 , compared with the Broadberry and Fremdling ratio of $102 .^{32}$ These differences are well within the 10 percent bounds suggested by Broadberry for this type of work. ${ }^{33}$ Second, note that if we compare the pattern of comparative productivity performance across sectors in 1935 from Table 3 with the pattern for 1907 in Table 2, there is a high degree of persistence. Germany had a labor productivity lead in heavy industries such as chemicals and metals in both years, while Britain had a persistent labor productivity lead in light industries such as textiles and clothing, and food, drink, and tobacco. Third, note that this pattern of stronger German productivity performance in heavy industry and better British productivity performance in light industry is as clear in the Fremdling, de Jong, and Timmer benchmark as it is in the Broadberry and Fremdling benchmark. ${ }^{34}$

\section{Revisions to the German Time Series Data}

The British historical national accounts for this period are uncontroversial and we employ Feinstein's index of production for manufacturing, as in Broadberry's previous work. ${ }^{35}$ Employment data for Britain are also derived from Feinstein, but with some interpolation for the pre1920 period, using the cyclical pattern in Feinstein's total employment series. ${ }^{36}$ Germany's historical national accounts are rather more controversial, however. A widely used industrial production index was calculated by Hoffmann. ${ }^{37}$ This index is based mainly on physical output series for 12 industries, but includes construction and the utilities as well as manufacturing. To be comparable with Feinstein's index for Britain, Hoffmann's index of total industrial production thus needs to be recalculated to cover only manufacturing, as in Broadberry's earlier work. ${ }^{38}$

Hoffmann's industrial production index was calculated from time series of physical output for 11 industries and a labor income series for one industry (metal processing). ${ }^{39}$ These 12 series were aggregated into a comprehensive industrial production index using net output weights. However, because reliable estimates of industrial net output for Ger-

\footnotetext{
${ }^{32}$ Fremdling, de Jong and Timmer, "British and German Manufacturing"; and Broadberry and Fremdling, "Comparative Productivity."

${ }^{33}$ Broadberry, "Manufacturing."

${ }^{34}$ Fremdling, de Jong, and Timmer, "British and German Manufacturing"; and Broadberry and Fremdling, "Comparative Productivity."

${ }^{35}$ Feinstein, National Income; and Broadberry, Productivity Race.

${ }^{36}$ Feinstein, National Income.

${ }^{37}$ Hoffmann, Das Wachstum.

${ }^{38}$ Feinstein, National Income; Hoffmann, Das Wachstum; and Broadberry, "Manufacturing."

${ }^{39}$ Hoffmann, Das Wachstum, pp. 344-95.
} 
many are available only for 1936, Hoffmann came up with a procedure to create proxy net output weights for earlier years. ${ }^{40}$ For each industry, this involved taking net output per employee in 1936 and multiplying it by employment in the same industry in 1882, 1907, and 1933. The product of 1936 labor productivity and $1882(1907,1933)$ employment then gives the weight of each industry for the years 1871-1895 (18951913, 1925-1938). Because we are interested in manufacturing, we will work with the ten industries excluding construction and the utilities.

We will report first the results of time series projection using the Hoffmann industrial production index recalculated on to a manufacturing-only basis by Broadberry. ${ }^{41}$ We will then construct two alternative projections to take account of recent criticisms of the Hoffmann index. ${ }^{42}$

One of the most important output series used by Hoffmann has been criticized recently. Ritschl presents a new time series for metal processing, the most important branch of German industry, for the years 1913 and 1925-1938, which suggests that the level of output in the interwar period was much lower relative to the prewar period than in the Hoffmann series. ${ }^{43}$ Ritschl believes that the Hoffmann index fails to reflect a substantial shift in the distribution of income in favor of labor, which occurred across World War I. Because the production index for metal processing is calculated by dividing labor income by a constant labor income share, the hypothesis of a nonconstant labor income share in metal processing is quite important. ${ }^{44}$ As we shall see later, however, Burhop and Wolff's income-based estimates suggest the alternative possibility that Hoffmann underestimated the pre-World War I level of capital income. ${ }^{45} \mathrm{~A}$ further criticism of the time series used by Hoffmann is made by Burhop and Wolff, who derive a new index for industrial output for the years 1851 to 1913 based on re-estimated industrial income data. ${ }^{46}$

Two indices of manufacturing output in Germany between 1871 and 1938 are plotted in Figure 1. First, there is the original Hoffmann industrial production index adjusted on to a manufacturing-only basis by Broadberry. ${ }^{47}$ Second, there is an index including Ritschl's correction

\footnotetext{
${ }^{40}$ Ibid., pp. 389-95.

${ }^{41}$ Hoffmann, Das Wachstum; and Broadberry, Productivity Race.

${ }^{42}$ Hoffmann, Das Wachstum.

${ }^{43}$ Ritschl, "Spurious Growth"; and Hoffmann, Das Wachstum.

${ }^{44}$ It is not clear how Ritschl treats the territorial losses of Germany after World War I. Territories covering about 35 percent of German 1913 steel output were lost after the War. Ritschl fixes output of metal processing industry to $1913=100$, but it is not clear if he uses 1913 territory or 1921 territory to do this.

${ }^{45}$ Burhop and Wolff, "Compromise Estimate."

46 Ibid.

${ }^{47}$ Hoffmann, Das Wachstum; and Broadberry, Productivity Race.
} 


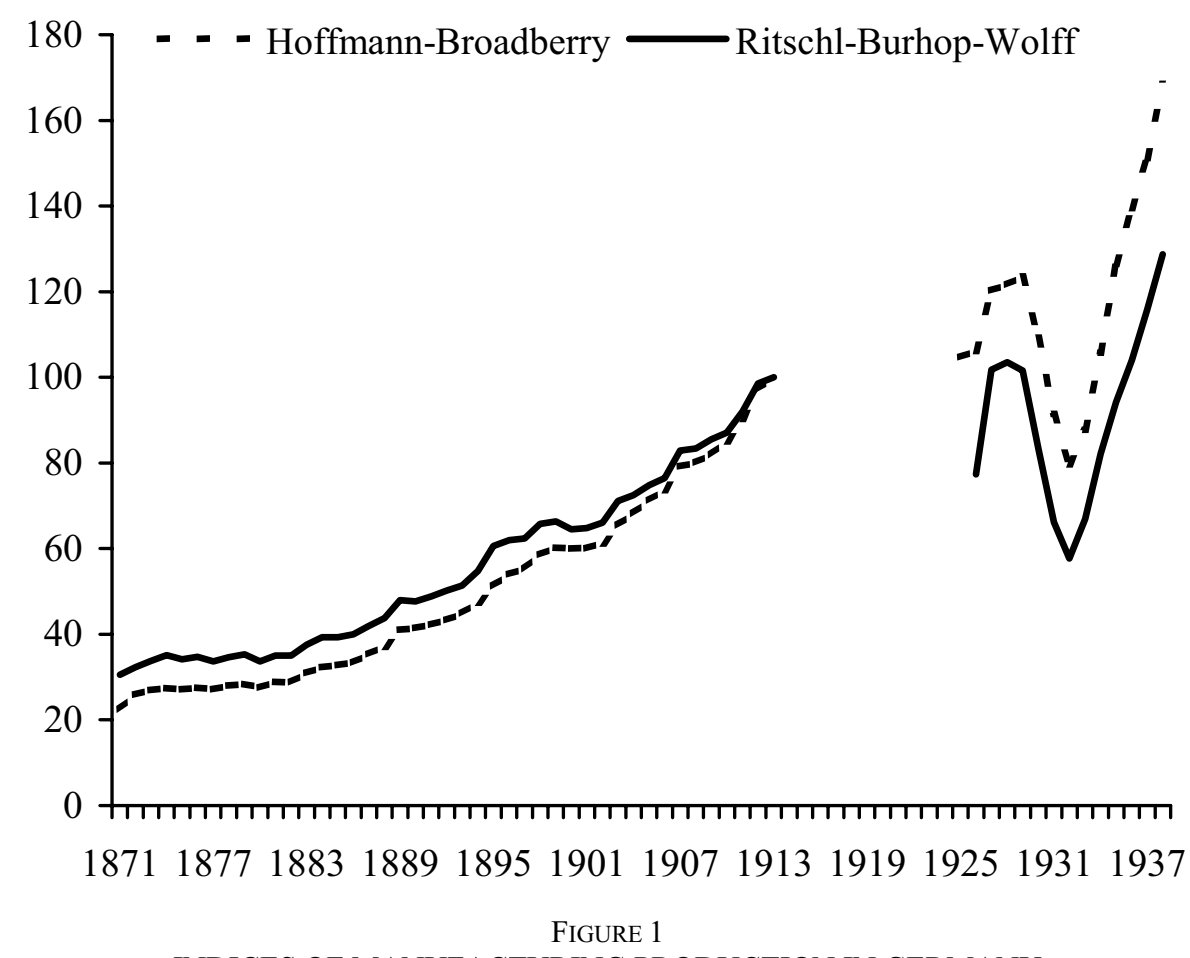

INDICES OF MANUFACTURING PRODUCTION IN GERMANY

Sources: Broadberry, Productivity Race, pp. 42-44, based on Hoffmann, Das Wachstum; Ritschl, "Spurious Growth," p. 216, col. 4; and Burhop and Wolff, "Compromise Estimate," pp. 652-53. Industrial production indices are adjusted for the weight of utilities and construction according to Hoffmann, Das Wachstum, pp. 390-95, cols. 11 and 12.

for the interwar period, as well as Burhop and Wolff's correction for the prewar period. ${ }^{48}$ For the prewar period, the Burhop and Wolff index is slightly above the level displayed by Hoffmann's original data, especially for the 1870 s to $1890 \mathrm{~s} .{ }^{49}$ Large differences can be noted between Hoffmann's original data and the manufacturing output index based on Ritschl's modification. Generally, Ritschl's index is well below the level displayed by Hoffmann's original data. ${ }^{50}$

\section{Results}

Figure 2 displays the time series projection from the 1935 Broadberry/Fremdling benchmark estimate for comparative Germany/U.K.

\footnotetext{
${ }^{48}$ Ritschl, "Spurious Growth"; and Burhop and Wolff, "Compromise Estimate."

${ }^{49}$ Ibid.; and Hoffmann, Das Wachstum.

${ }^{50}$ Ritschl, "Spurious Growth"; and Hoffmann, Das Wachstum.
} 


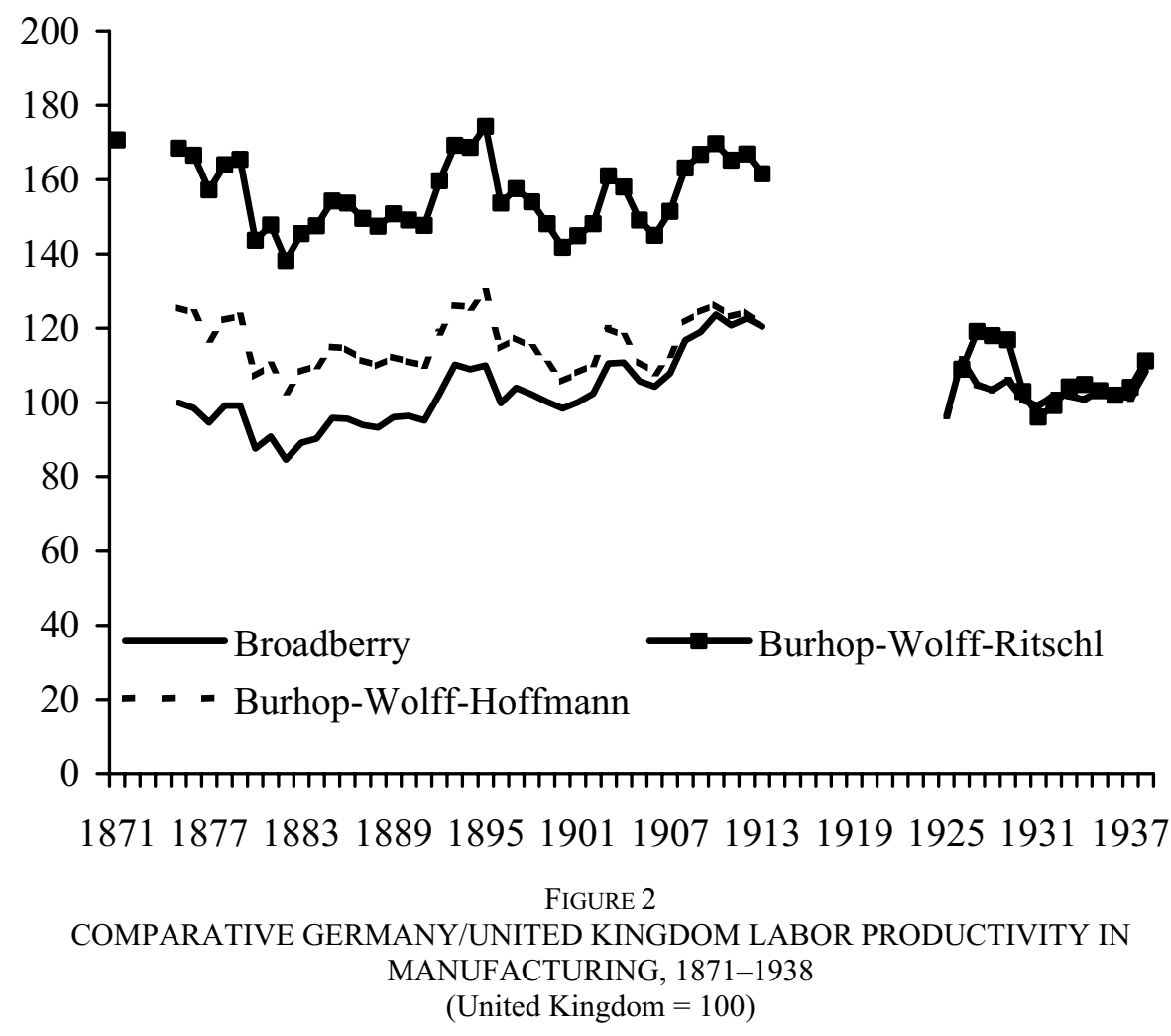

Sources: U.K. output: Broadberry, Productivity Race, pp. 42-44, based on Feinstein, National Income; U.K. employment: Broadberry, Productivity Race, pp. 42-44, based on Feinstein, $\mathrm{Na}$ tional Income; German output: Broadberry, Productivity Race, pp. 42-44, based on Hoffmann, Das Wachstum; Burhop and Wolff, "Compromise Estimate"; and Ritschl, "Spurious Growth," p. 216, col. 4; German employment: Broadberry, Productivity Race, pp. 42-44, based on Hoffmann, Das Wachstum.

labor productivity in manufacturing. ${ }^{51}$ The first projection, labeled Broadberry, uses the Hoffmann index of German manufacturing output. $^{52}$ Note first that the projected values for 1907 and 1908 are 107.8 and 116.7 respectively, reassuringly close to our circa 1907 benchmark value of 105.0. If, alternatively, the 1907 benchmark is used as the basis of the projections, this gives projected values for 1935 and 1936 of 100.5 and 99.3 , respectively. This is again reassuringly close to all the circa 1935 benchmarks ranging from 102 to 107.

The second projection in Figure 2, labeled "Burhop-WolffHoffmann," uses Burhop and Wolff's data for the prewar period and

\footnotetext{
${ }^{51}$ Broadberry and Fremdling, "Comparative Productivity."

${ }^{52}$ Broadberry, Productivity Race; and Hoffmann, Das Wachstum.
} 
Hoffmann's data for the interwar period. ${ }^{53}$ This results in a similar picture to the Broadberry estimate for the period from the turn of the century to 1938 . However, between the 1870 s and the 1890 s, this series suggests that German labor productivity was already ahead of the British level, although the difference is not that great. Reconciliation of this time series finding with cross-sectional evidence would require a new benchmark for the 1870s. With the data available at the moment, that does not seem feasible, so this must remain an open issue.

Finally, we calculated an index using Burhop and Wolff's data for the prewar period and Ritschl's data for the interwar period. ${ }^{54}$ Using this time series to extrapolate from the 1935 benchmark backwards to the 1907 benchmark in Figure 2 leads to a German labor productivity lead over Britain of more than 50 percent in 1907-1908, about 40 percentage points above the 1907 benchmark estimate, and a rather unlikely finding. It thus seems that Ritschl's modifications to Hoffmann's index of industrial production need further adjustment. ${ }^{55}$

\section{INCOME BASED ESTIMATES}

We can compare these findings based on output data with alternative estimates of comparative Germany/U.K. labor productivity in manufacturing based on income data. This is important because Fremdling found labor productivity in German industry to vary between around half to two-thirds of the British level between the 1870s and World War I, which appears to conflict strongly with our findings of broadly equal labor productivity. ${ }^{56}$ The most important adjustment follows from the use of Burhop and Wolff's allowance for Hoffmann's underestimation of capital income in the pre-1914 period. ${ }^{57}$ This was noted by Fremdling, who argued that Hoffmann assumed far too low a rate of return on capital, but Fremdling did not produce an alternative estimate. ${ }^{58}$ The second adjustment arises from the fact that our estimates are restricted to manufacturing, although this makes only a small difference. The third adjustment arises from the fact that Fremdling used PPPs for commodity output, including agricultural as well as industrial commodities. We calculate the PPPs solely on the basis of manufactured products, which makes a big difference because protection in Germany ensured that the price of agricultural products did not fall in line with

\footnotetext{
${ }^{53}$ Burhop and Wolff, "Compromise Estimate"; and Hoffmann, Das Wachstum.

${ }^{54}$ Burhop and Wolff, "Compromise Estimate"; and Ritschl, "Spurious Growth."

${ }^{55}$ Ibid.; and Hoffmann, Das Wachstum.

${ }^{56}$ Fremdling, "Productivity Comparison."

${ }^{57}$ Burhop and Wolff, "Compromise Estimate"; and Hoffmann, Das Wachstum.

${ }^{58}$ Fremdling, "German National Accounts"; and Hoffmann, Das Wachstum.
} 
TABLE 4

INCOME BASED ESTIMATES OF COMPARATIVE GERMANY/UNITED KINGDOM LABOR PRODUCTIVITY IN MANUFACTURING BEFORE WORLD WAR I

\begin{tabular}{|c|c|c|c|c|c|c|}
\hline & $\begin{array}{c}\text { German } \\
\text { Net Output } \\
\text { per Worker } \\
(\mathrm{M}) \\
\end{array}$ & $\begin{array}{c}\text { Average } \\
\text { PPP } \\
\text { (M per } £ \text { ) }\end{array}$ & $\begin{array}{c}\text { German } \\
\text { Net Output } \\
\text { per Worker } \\
(£) \\
\end{array}$ & $\begin{array}{l}\text { U.K. Net } \\
\text { Output } \\
\text { per } \\
\text { Worker } \\
(£) \\
\end{array}$ & $\begin{array}{c}\text { Germany/U.K. } \\
\text { Output per } \\
\text { Worker at PPP } \\
\text { (U.K. = 100) }\end{array}$ & $\begin{array}{c}\text { Germany/U.K. } \\
\text { Output per } \\
\text { Worker at } \\
\text { Exchange Rate } \\
\text { (U.K.=100) }\end{array}$ \\
\hline $1875-1884$ & 1,428 & 22.3 & 64.0 & 69.3 & 92.4 & 101.0 \\
\hline 1885-1894 & 1,484 & 23.0 & 64.5 & 72.9 & 88.5 & 99.7 \\
\hline 1895-1904 & 1,679 & 23.7 & 70.8 & 84.6 & 83.7 & 97.3 \\
\hline 1905-1913 & 2,159 & 23.2 & 93.7 & 96.1 & 97.5 & 110.1 \\
\hline
\end{tabular}

Sources: German net output per worker from Burhop and Wolff, "Compromise Estimate"; U.K. net output per worker derived from Feinstein, National Income; Average PPP derived from Fremdling, "Productivity Comparison," using only manufactured products.

agricultural prices in Britain, where markets remained open to cheap grain and meat from the New World. ${ }^{59}$ But even here, it is worth noting that the particular industrial products for which Fremdling was able to obtain data are biased towards finding a higher price level in Germany. ${ }^{60}$ Fremdling provides series for the prices of pig iron, cotton yarn, and flour to represent the metals, textiles, and food sectors, respectively. ${ }^{61}$ However, Germany imported pig iron from Britain to make steel that was competitive on world markets, and also imported cotton yarn from Britain to produce cotton cloth that was competitive on world markets. Also, the principal ingredient of flour was grain, the price of which was kept artificially high in Germany through agricultural protection.

In Table 4, we derive British net output per employee from information in the historical national accounts combined with the 1907 Census of Production. This involves using Feinstein's time series of NNP from the income side to project the value of net output in manufacturing from the 1907 Census, and the time series of employment in manufacturing from Broadberry to project the 1911 manufacturing labor figure from Feinstein. ${ }^{62}$ The assumption of a constant share of manufacturing in current price national income is consistent with the figures of Phyllis Deane and William Cole. ${ }^{63}$ For Germany, the 1907 share of manufacturing output in total industrial output is calculated using the weights given by Hoffmann. ${ }^{64}$ This is then multiplied with the 1913 total industrial

\footnotetext{
${ }^{59}$ In addition, some heavy industrial products were also protected by import duties.

${ }^{60}$ Fremdling, "Productivity Comparison."

${ }^{61}$ Ibid., p. 30 .

${ }^{62}$ Feinstein, National Income, table 1; Broadberry, Productivity Race, p. 43; and Feinstein, National Income, table 60.

${ }^{63}$ Deane and Cole, British Economic Growth, p. 166.

${ }^{64}$ Hoffmann, Das Wachstum, p. 390.
} 
output from Burhop and Wolff to yield an estimate of manufacturing net output that is substantially higher than that implicit in Hoffman's income side data. ${ }^{65}$ This yields a 1913 manufacturing labor productivity of M 2,413. The income-based 1913 benchmark for Germany is projected backwards using the nominal NNP data together with the assumption of a constant share of manufacturing in Germany. Combined with data on manufacturing employment, this yields an income-based estimate of manufacturing labor productivity. These data series for the two countries can be compared using market exchange rates or PPPs, as in Table 4.

The whole period is divided into four sub-periods, $1875-1884$, 18851894, 1895-1904, and 1905-1913. The average PPPs for manufactured products move more closely in line with the exchange rate than Fremdling's PPPs for a wider range of commodities, which were heavily influenced by protected agricultural products. ${ }^{66}$ Using these PPPs, German manufacturing output per worker was slightly below British labor productivity throughout the period. However, using the market exchange rate instead of PPPs, labor productivity was slightly higher in Germany. The PPPs most likely understate true German productivity, for the reasons outlined previously, while the market exchange rate probably overstates German productivity. Taken together, the two measures suggest broadly equal labor productivity in German and British manufacturing before World War I. Correcting the Hoffmann income data for underestimation of capital income therefore removes a large part of the discrepancy between the income-based and outputbased measures. ${ }^{67}$

\section{CONCLUSION}

Labor productivity in manufacturing was about the same in Germany and Britain from the late nineteenth century to World War II, supporting the earlier findings of Broadberry ${ }^{68}$ Benchmark estimates for 1907 and 1935 show Germany ahead in heavy industry (chemicals, metals), whereas Britain had higher productivity in the light industries, espe-

\footnotetext{
${ }^{65}$ Burhop and Wolff, "Compromise Estimate,” p. 642; and Hoffmann, Das Wachstum.

${ }^{66}$ Fremdling, "Productivity Comparison," p. 33.

${ }^{67}$ Engel, "Die erwerbstätingen juristischen Personen," p. 468, gives some support to our hypothesis of an equal manufacturing labor productivity in Britain and Germany around 1880. According to our extrapolation, nominal manufacturing labor productivity was $1,428 \mathrm{M}$ between 1875 and 1884. Engel estimates a gross manufacturing output per worker of 3,600 M for the early 1870 s. A reasonable assumption is that net output per worker (labor productivity) is about 40 percent of gross output, or 1,440 Marks, a figure quite close to our extrapolation.

${ }^{68}$ Broadberry, Productivity Race.
} 
cially in textiles, and food, drink, and tobacco. Our new 1907 benchmark estimate thus offers qualified support to the traditional view of Williams, Gerschenkron, and Landes, who saw Germany as modernizing before World War I on the basis of heavy industry. ${ }^{69}$ However, it also encompasses the newer historical national accounting viewpoint, which notes that the high-productivity modernized parts of the German economy co-existed with low-productivity traditional parts, so that whole-economy productivity was substantially higher in Britain than in Germany.

Starting from Broadberry and Fremdling's 1935 benchmark estimate of comparative labor productivity in manufacturing, we project backwards to 1871 and forwards to 1938 using new time series data of Germany's manufacturing output. ${ }^{70}$ The two benchmark estimates are broadly consistent with the Hoffmann and Burhop and Wolff indices of industrial output. ${ }^{71}$ However, Burhop and Wolff's industrial output data suggest a German labor productivity lead in manufacturing already during the 1870s. Future research should check this hypothesis with a new benchmark estimate. So far, however, the available data are not sufficient to calculate such an early benchmark estimate.

We support our finding for the pre-World War I period using new income data from Burhop and Wolff. ${ }^{72}$ Using these data, we rework Fremdling's income-based estimate of comparative labor productivity in manufacturing. ${ }^{73}$ We find broadly equal levels of manufacturing labor productivity in the two countries throughout the period 1875-1913, as suggested by our output-based estimates. Overall, we are able to reconcile most of the existing time series and benchmark estimates of comparative Germany/U.K. labor productivity in manufacturing before World War II.

\footnotetext{
${ }^{69}$ Williams, Made in Germany; Gerschenkron, Economic Backwardness; and Landes, Unbound Prometheus.

${ }^{70}$ Broadberry and Fremdling, "Comparative Productivity."

${ }^{71}$ Hoffmann, Das Wachstum, p. 390; and Burhop and Wolff, "Compromise Estimate."

${ }^{72}$ Ibid.

${ }^{73}$ Fremdling, "Productivity Comparison."
} 


\section{Appendix 1: Underlying Data for 1907 Benchmark}

General Note: individual figures in the tables have been rounded, whereas the calculations use unrounded figures. This results in a few very small apparent discrepancies.

APPENDIX TABLE 1

GENERAL CHEMICALS

\begin{tabular}{|c|c|c|c|c|c|}
\hline \multicolumn{6}{|c|}{ United Kingdom } \\
\hline & $\begin{array}{l}\text { Quantity } \\
\text { (tons) }\end{array}$ & $\begin{array}{l}\text { Value } \\
(£ 000)\end{array}$ & $\begin{array}{l}\text { Unit Value } \\
\text { (£ per ton) }\end{array}$ & $\begin{array}{l}\text { Employment } \\
(000)\end{array}$ & $\begin{array}{l}\text { Output Per Employee } \\
(£)\end{array}$ \\
\hline Sulphuric acid & 475,000 & 861 & 1.81 & & \\
\hline Anthracene & 1,482 & 8 & 5.40 & & \\
\hline Napthalene & 12,750 & 33 & 2.59 & & \\
\hline Pitch & 537,000 & 684 & 1.27 & & \\
\hline Total of above & & 1,586 & & & \\
\hline Total industry & & 24,025 & & 52.257 & 459.75 \\
\hline \multicolumn{6}{|c|}{ Germany } \\
\hline & $\begin{array}{l}\text { Quantity } \\
\text { (tonnes) }\end{array}$ & $\begin{array}{l}\text { Value } \\
\text { (M000) }\end{array}$ & $\begin{array}{l}\text { Unit Value } \\
\text { (M per tonne) }\end{array}$ & $\begin{array}{l}\text { Employment } \\
(000)\end{array}$ & $\begin{array}{l}\text { Output Per Employee } \\
\text { (M) }\end{array}$ \\
\hline Sulphuric acid & $1,150,524$ & 41,159 & 35.77 & & \\
\hline Anthracene & 4,026 & 646 & 160.46 & & \\
\hline Napthalene & 36,397 & 2,714 & 74.57 & & \\
\hline Pitch & 402,676 & 12,986 & 32.25 & & \\
\hline Total of above & & 57,505 & & & \\
\hline Total industry & & 123,478 & & 9.830 & $12,561.34$ \\
\hline \multicolumn{6}{|c|}{ PPP } \\
\hline & & & & & M per $£$ \\
\hline U.K. weights & & & & & 22.03 \\
\hline German weights & & & & & 21.20 \\
\hline Geometric mean & & & & & 21.61 \\
\hline
\end{tabular}

Notes: Data were first obtained on the quantities and values of matched chemical outputs in both countries. A PPP was calculated from the unit values, taking care to convert British tons into German tonnes ( 1 ton $=1.016$ tonnes), and taking the geometric mean of U.K. and German weights. The PPP was applied to the value of output per employee, since the German data on input values needed to calculate net output are incomplete.

Comparing output per employee of M12,561.34 in Germany and $£ 459.75$ in the United Kingdom at a PPP of $£ 1=$ M21.61 yields a comparative Germany/U.K. labor productivity ratio of 126.6. German data are for 1908 .

Sources: United Kingdom: Board of Trade, Final Report, pp. 571-73; Germany: Kaiserliches Statistisches Amt, "Ergebnisse," pp. 59-63; and "Die Ergebnisse," p. 108. 
APPENDIX TABLE 2

COKE

\begin{tabular}{|c|c|c|c|c|}
\hline & \multicolumn{2}{|c|}{ United Kingdom } & \multicolumn{2}{|c|}{ Germany } \\
\hline & Units & Values & Units & Values \\
\hline Output volume & 000 tons & 11,344 & 000 tonnes & 22,723 \\
\hline Output value & $£ 000$ & 9,516 & M000 & 388,187 \\
\hline Unit value & $£$ per ton & 0.84 & M per tonne & 17.08 \\
\hline Industry output value & $£ 000$ & 10,140 & M000 & 464,507 \\
\hline Industry employment & 000 & 10.958 & 000 & 24.535 \\
\hline Adjusted employment & 000 & 10.284 & 000 & 20.504 \\
\hline Output per employee & tons & 1,103 & & \\
\hline Output per employee & tonnes & 1,121 & tonnes & 1,108 \\
\hline Net output & $£ 000$ & 2,993 & M000 & 125,747 \\
\hline $\begin{array}{l}\text { Net output per em- } \\
\text { ployee }\end{array}$ & $£$ & 273.13 & $\mathrm{M}$ & 5,125 \\
\hline PPP & & & M per $£$ & 20.77 \\
\hline $\begin{array}{l}\text { Germany/U.K. net } \\
\text { output per employee }\end{array}$ & & & U.K. $=100$ & 90.4 \\
\hline
\end{tabular}

Notes: Data were first collected on quantities and values of coke produced in the two countries. Employment was adjusted in line with the ratio of the value of the output of these principal products to the total value of output in the industry.

Comparing output per employee of 1,108 tonnes in Germany with 1,121 tonnes in the United Kingdom yields a comparative Germany/U.K. labor productivity ratio of 98.9. Finally, a crosscheck was carried out by comparing net output per employee in the two countries at the PPP obtained from the unit values, including extra information on prices of tar and pitch as well as coke. The results using net output are reassuringly close to the results obtained with physical indicators. German data are for 1908.

Sources: United Kingdom: Board of Trade, Final Report, pp. 69-70; Germany: Kaiserliches Statistisches Amt, "Ergebnisse," pp. 4-5. 


\begin{tabular}{|c|c|c|c|c|c|}
\hline \multicolumn{6}{|c|}{$\begin{array}{l}\text { APPENDIX TABLE } 3 \\
\text { IRON AND STEEL } \\
\end{array}$} \\
\hline \multicolumn{6}{|c|}{ United Kingdom } \\
\hline & $\begin{array}{l}\text { Quantity } \\
\text { (000 tons) }\end{array}$ & $\begin{array}{l}\text { Value } \\
(£ 000)\end{array}$ & $\begin{array}{l}\text { Unit Value } \\
\text { (£ per ton) }\end{array}$ & $\begin{array}{l}\text { Employment } \\
(000)\end{array}$ & $\begin{array}{l}\text { Output per } \\
\text { Employee } \\
\text { (£) }\end{array}$ \\
\hline Pig iron & 6,988 & 23,482 & 3.36 & & \\
\hline Cast iron & 2,094 & 16,854 & 8.05 & & \\
\hline Rails & 1,085 & 7,257 & 6.69 & & \\
\hline Plates and sheets & 1,876 & 17,282 & 9.21 & & \\
\hline Wire & 513 & 4,083 & 7.96 & & \\
\hline Total of above & & 68,958 & & & \\
\hline Total industry & & 105,322 & & & \\
\hline Total industry (net) & & 30,048 & & 261.666 & 114.83 \\
\hline \multicolumn{6}{|c|}{ Germany } \\
\hline
\end{tabular}

\begin{tabular}{|c|c|c|c|c|c|}
\hline & $\begin{array}{c}\text { Quantity } \\
\text { (000 tonnes) }\end{array}$ & $\begin{array}{l}\text { Value } \\
\text { (M000) }\end{array}$ & $\begin{array}{l}\text { Unit Value } \\
\text { (M per tonne) }\end{array}$ & $\begin{array}{c}\text { Employment } \\
(000)\end{array}$ & $\begin{array}{c}\text { Output per } \\
\text { Employee } \\
\text { (M) }\end{array}$ \\
\hline Pig iron & 10,681 & 657,152 & 61.53 & & \\
\hline Cast iron & 2,416 & 481,851 & 199.45 & & \\
\hline Rails & 1,635 & 194,842 & 119.15 & & \\
\hline Plates and sheets & 1,426 & 216,055 & 151.56 & & \\
\hline Wire & 1,062 & 130,217 & 122.59 & & \\
\hline Total of above & & $1,680,117$ & & & \\
\hline Total industry & & $3,586,780$ & & & \\
\hline \multirow[t]{2}{*}{ Total industry (net) } & & 970,900 & & 315.895 & $3,073.48$ \\
\hline & & PPF & & & \\
\hline
\end{tabular}

\begin{tabular}{lr}
\hline & M per $£$ \\
\hline U.K. weights & 19.64 \\
German weights & 19.20 \\
Geometric mean & 19.42 \\
\hline
\end{tabular}

Notes: Data were first obtained on the quantities and values of matched outputs in both countries. A PPP was calculated from the unit values, taking care to convert British tons into German tonnes, and taking the geometric mean of U.K. and German weights. The PPP was applied to net output per employee, available for both countries.

Comparing net output per employee of M3,073.48 in Germany and $£ 114.83$ in the United Kingdom at a PPP of $£ 1=$ M19.42 yields a comparative Germany/U.K. labor productivity ratio of 137.8. German data are for 1908 .

Sources: United Kingdom: Board of Trade, Final Report, pp. 171-75; Germany: Kaiserliches Statistisches Amt, "Ergebnisse," pp. 46-50. 
APPENDIX TABLE 4 NONFERROUS METALS

\begin{tabular}{|c|c|c|c|c|c|}
\hline \multicolumn{6}{|c|}{ United Kingdom } \\
\hline & $\begin{array}{l}\text { Quantity } \\
\text { (tons) }\end{array}$ & $\begin{array}{l}\text { Value } \\
(£ 000)\end{array}$ & $\begin{array}{l}\text { Unit Value } \\
\text { (£ per ton) }\end{array}$ & $\begin{array}{l}\text { Employment } \\
(000)\end{array}$ & $\begin{array}{c}\text { Output per } \\
\text { Employee } \\
(£)\end{array}$ \\
\hline Copper, unwrought & 40,900 & 3,422 & 83.67 & & \\
\hline Zinc, unrefined & 38,000 & 918 & 24.16 & & \\
\hline Total of above & & 4,340 & & & \\
\hline Total industry & & 26,270 & & & \\
\hline Total industry (net) & & 4,458 & & 31.868 & 139.89 \\
\hline \multicolumn{6}{|c|}{ Germany } \\
\hline & $\begin{array}{l}\text { Quantity } \\
\text { (tonnes) }\end{array}$ & $\begin{array}{l}\text { Value } \\
\text { (M000) }\end{array}$ & $\begin{array}{l}\text { Unit Value } \\
\text { (M per tonne) }\end{array}$ & $\begin{array}{l}\text { Employment } \\
(000)\end{array}$ & $\begin{array}{c}\text { Output per } \\
\text { Employee } \\
\text { (M) }\end{array}$ \\
\hline Copper, unwrought & 16,568 & 20,926 & 1,263 & & \\
\hline Zinc, unrefined & 227,695 & 90,017 & 395 & & \\
\hline Total of above & & 110,943 & & & \\
\hline Total industry & & 349,115 & & & \\
\hline Total industry (net) & & 74,268 & & 22.952 & 3,236 \\
\hline \multicolumn{6}{|c|}{ PPP } \\
\hline & & & & & M per $£$ \\
\hline U.K. weights & & & & & 13.95 \\
\hline German weights & & & & & 15.38 \\
\hline Geometric mean & & & & & 14.65 \\
\hline
\end{tabular}

Notes: Data were first obtained on the quantities and values of matched outputs in both countries. A PPP was calculated from the unit values, taking care to convert British tons into German tonnes, and taking the geometric mean of U.K. and German weights. The PPP was applied to net output per employee, available for both countries

Comparing net output per employee of M3,236 in Germany and £139.89 in the United Kingdom at a PPP of $£ 1=$ M14.65 yields a comparative Germany/U.K. labor productivity ratio of 157.9. German data are for 1908 .

Sources: United Kingdom: Board of Trade, Final Report, pp. 264-66; Germany: Kaiserliches Statistisches Amt, "Ergebnisse," p. 2. 


\begin{tabular}{|c|c|c|c|c|c|}
\hline \multicolumn{6}{|c|}{$\begin{array}{l}\text { APPENDIX TABLE } 5 \\
\text { MOTOR VEHICLES }\end{array}$} \\
\hline \multicolumn{6}{|c|}{ United Kingdom } \\
\hline & $\begin{array}{c}\text { Quantity } \\
\text { (units) }\end{array}$ & $\begin{array}{l}\text { Value } \\
(£ 000)\end{array}$ & Unit Value (£) & $\begin{array}{c}\text { Employment } \\
(000)\end{array}$ & $\begin{array}{l}\text { Output per } \\
\text { Employee } \\
(£)\end{array}$ \\
\hline Motor vehicles & 8,800 & 2,948 & 335 & & \\
\hline Chassis & 1,500 & 637 & 425 & & \\
\hline Motor cycles & 3,700 & 137 & 37 & & \\
\hline Total of above & & 3,722 & & & \\
\hline Total industry & & 11,580 & & & \\
\hline Total industry (net) & & 5,901 & & 54.043 & 109.19 \\
\hline \multicolumn{6}{|c|}{ Germany } \\
\hline & $\begin{array}{c}\text { Quantity } \\
\text { (units) }\end{array}$ & $\begin{array}{l}\text { Value } \\
\text { (M000) }\end{array}$ & $\begin{array}{l}\text { Unit Value } \\
\text { (M) }\end{array}$ & $\begin{array}{c}\text { Employment } \\
(000)\end{array}$ & $\begin{array}{c}\text { Output per } \\
\text { Employee } \\
\text { (M) }\end{array}$ \\
\hline Motor vehicles & 7,318 & 47,841 & 6,537 & & \\
\hline Chassis & 2,126 & 20,139 & 9,472 & & \\
\hline Motor cycles & 3,703 & 2,247 & 607 & & \\
\hline Total of above & & 70,227 & & & \\
\hline Total industry & & 73,000 & & & \\
\hline Total industry (net) & & 37,000 & & 19.221 & 1,925 \\
\hline \multicolumn{6}{|c|}{ PPP } \\
\hline & & & & & M per $£$ \\
\hline $\begin{array}{l}\text { U.K. weights } \\
\text { German weights } \\
\text { Geometric mean }\end{array}$ & & & & & $\begin{array}{l}19.88 \\
19.45 \\
19.66\end{array}$ \\
\hline
\end{tabular}

Notes: Data were first obtained on the quantities and values of matched outputs in both countries. A PPP was calculated from the unit values, taking care to convert British tons into German tonnes, and taking the geometric mean of U.K. and German weights. The PPP was applied to net output per employee, available for both countries

Comparing net output per employee of M1,925 in Germany and £109.19 in the United Kingdom at a PPP of $£ 1=$ M19.66 yields a comparative Germany/U.K. labor productivity ratio of 89.7. German data are for 1909. The estimate in Broadberry and Fremdling, "Comparative Productivity," showing a substantial German labor productivity lead in this sector resulted from the use of too high a figure for U.K. employment.

Sources: United Kingdom: Board of Trade, Final Report, pp. 203-04; Germany: Kaiserliches Statistisches Amt, "Ergebnisse," pp. 65, 67. 


\begin{tabular}{|c|c|c|c|c|}
\hline \multicolumn{5}{|c|}{$\begin{array}{c}\text { APPENDIX TABLE } 6 \\
\text { COTTON }\end{array}$} \\
\hline & \multicolumn{2}{|c|}{ United Kingdom } & \multicolumn{2}{|c|}{ Germany } \\
\hline & Units & Values & Units & Values \\
\hline Output volume & $000 \mathrm{lb}$ & $1,487,367$ & $000 \mathrm{~kg}$ & 358,935 \\
\hline Output value & $£ 000$ & 78,304 & M000 & 644,464 \\
\hline Unit value & $£$ per $\mathrm{lb}$ & 0.05 & M per $\mathrm{kg}$ & 1.80 \\
\hline Industry output value & $£ 000$ & 174,610 & M000 & 644,464 \\
\hline Industry employment & 000 & 572.062 & 000 & 159.432 \\
\hline Adjusted employment & 000 & 256.542 & 000 & 159.432 \\
\hline Output per employee & $\mathrm{lb}$ & 5,798 & & \\
\hline Output per employee & $\mathrm{kg}$ & 2,630 & $\mathrm{~kg}$ & 2,251 \\
\hline
\end{tabular}

Notes: Data were first collected on quantities and values of yarn produced in the two countries. Employment was adjusted in line with the ratio of the value of this output to the total value of output in the industry.

Comparing output per employee of 2,251 kg in Germany with $2,630 \mathrm{~kg}$ in the United Kingdom yields a comparative Germany/U.K. labor productivity ratio of 85.6. German data are for 1907.

Sources: United Kingdom: Board of Trade, Final Report, pp. 337-39; Germany, output: Kaiserliches Statistisches Amt, Statistisches Jarhbuch, vol. 30, p. 80; "Berufs- und Betriebszählung," pp. 253-54; Germany, employment: Kaiserliches Statistisches Amt, "Ergebnisse,” p. 69.

APPENDIX TABLE 7

SILK

\begin{tabular}{|c|c|c|c|c|}
\hline & \multicolumn{2}{|c|}{ United Kingdom } & \multicolumn{2}{|c|}{ Germany } \\
\hline & Units & Values & Units & Values \\
\hline Output volume & $000 \mathrm{lb}$ & 2,711 & $000 \mathrm{~kg}$ & 9,940 \\
\hline Output value & $£ 000$ & 1,330 & M000 & 337,745 \\
\hline Unit value & $£$ per $\mathrm{lb}$ & 0.49 & $\mathrm{M}$ per $\mathrm{kg}$ & 33.98 \\
\hline Industry output value & $£ 000$ & 5,236 & M000 & 337,745 \\
\hline Industry employment & 000 & 32.272 & 000 & 88.456 \\
\hline Adjusted employment & 000 & 8.197 & 000 & 88.456 \\
\hline Output per employee & $\mathrm{lb}$ & 331 & & \\
\hline Output per employee & $\mathrm{kg}$ & 150.0 & $\mathrm{~kg}$ & 112.4 \\
\hline
\end{tabular}

Notes: Data were first collected on quantities and values of the principal products in silk weaving and silk spinning in the two countries. Employment was adjusted in line with the ratio of the value of the output of these principal products to the total value of output in the industry.

Comparing output per employee of $112.4 \mathrm{~kg}$ in Germany with $150.0 \mathrm{~kg}$ in the United Kingdom yields a comparative Germany/U.K. labor productivity ratio of 74.9. German data are for 1907.

Sources: United Kingdom: Board of Trade, Final Report, pp. 358-59; Germany, output: Kaiserliches Statistisches Amt, "Ergebnisse," pp. 74-75; Germany, employment: Kaiserliches Statistisches Amt, Statistisches Jahrbuch, vol. 30, p. 80; "Berufs- und Betriebszählung," pp. 25354. 


\begin{tabular}{lccccc}
\multicolumn{3}{c}{$\begin{array}{c}\text { APPENDIX TABLE } 8 \\
\text { LEATHER }\end{array}$} \\
\hline \hline & \multicolumn{2}{c}{ United Kingdom } & & \multicolumn{2}{c}{ Germany } \\
\cline { 2 - 3 } \cline { 5 - 6 } & Units & Values & & Units & Values \\
\hline Output volume & $000 \mathrm{cwt}$ & 1,729 & & $000 \mathrm{~kg}$ & 137,272 \\
Output value & $£ 000$ & 11,080 & & M000 & 625,276 \\
Unit value & $£$ per cwt & 6.41 & & M per kg & 4.56 \\
Industry output value & $£ 000$ & 18,289 & & M000 & 675,320 \\
Industry employment & 000 & 28.910 & & 000 & 43.621 \\
Adjusted employment & 000 & 17.515 & & 000 & 40.389 \\
Output per employee & $\mathrm{cwt}$ & 98.718 & & & 3,399 \\
Output per employee & $\mathrm{kg}$ & 5,015 & $\mathrm{~kg}$ & \\
\hline
\end{tabular}

Notes: Data were first collected on quantities and values of leather production in the two countries. Employment was adjusted in line with the ratio of the value of the output of the principal products to the total value of output in the industry.

Comparing output per employee of 3,399 kg in Germany with 5,015 kg in the United Kingdom yields a comparative Germany/U.K. labor productivity ratio of 67.8. In Broadberry and Fremdling, "Comparative Productivity," U.K. output was underestimated. The current figures are to be preferred. German data are for 1910.

Sources: United Kingdom: Board of Trade, Final Report, pp. 675-76; Germany, output: Kaiserliches Statistisches Amt, "Ergebnisse," p. 78; Germany, employment: Kaiserliches Statistisches Amt, "Ergebnisse," p. 77; "Berufs- und Betriebszählung," p. 256.

APPENDIX TABLE 9 BREWING

\begin{tabular}{|c|c|c|c|c|}
\hline & \multicolumn{2}{|c|}{ United Kingdom } & \multicolumn{2}{|c|}{ Germany } \\
\hline & Units & Values & Units & Values \\
\hline Output volume & 000 barrels & 34,505 & & \\
\hline Output volume & m liters & 5,647 & $\mathrm{~m}$ liters & 7,371 \\
\hline Output value & $£ 000$ & 58,580 & & \\
\hline Industry output value & $£ 000$ & 67,250 & & \\
\hline Industry employment & 000 & 88.969 & 000 & 111.779 \\
\hline Adjusted employment & 000 & 77.499 & & \\
\hline Output per employee & liters & 72,866 & liters & 65,940 \\
\hline
\end{tabular}

Notes: Data were first collected on quantities of beer brewed in the two countries and the volume of employment.

Comparing output per employee of 65,940 liters in Germany with 72,866 liters in the United Kingdom yields a comparative Germany/U.K. labor productivity ratio of 90.5 . German data are for 1907.

Sources: United Kingdom: Board of Trade, Final Report, pp. 524-25; Germany: Kaiserliches Statistisches Amt, Statistisches Jahrbuch, vol. 30, pp. 82, 103. 
APPENDIX TABLE 10 TOBACCO

\begin{tabular}{lcccccc}
\hline \hline & \multicolumn{2}{c}{ United Kingdom } & & \multicolumn{2}{c}{ Germany } \\
\cline { 2 - 3 } \cline { 6 - 6 } & Units & Values & & Units & Values \\
\hline Output volume & $\mathrm{cwt}$ & 970,000 & & & \\
Output volume & $\mathrm{m} \mathrm{kg}$ & 49,278 & & $\mathrm{~m} \mathrm{~kg}$ & 23,071 \\
Output value & $£ 000$ & 23,452 & & & \\
Industry output value & $£ 000$ & 23,870 & & & \\
Industry employment & 000 & 37.648 & & 000 & \\
Adjusted employment & 000 & 36.989 & & & \\
Output per employee & $\mathrm{kg}$ & 1,332 & & $\mathrm{~kg}$ & 377 \\
\hline
\end{tabular}

Notes: Data were first collected on quantities of tobacco processed in the two countries and the volume of employment.

Comparing output per employee of $377 \mathrm{~kg}$ in Germany with 1,332 kg in the United Kingdom yields a comparative Germany/U.K. labor productivity ratio of 28.3. German data are for 1907. Sources: United Kingdom: Board of Trade, Final Report, pp. 538-39; Germany: Kaiserliches Statistisches Amt, Statistisches Jahrbuch, vol. 30, p. 275.

APPENDIX TABLE 11

SUGAR

\begin{tabular}{|c|c|c|c|c|}
\hline & \multicolumn{2}{|c|}{ United Kingdom } & \multicolumn{2}{|c|}{ Germany } \\
\hline & Units & Values & Units & Values \\
\hline Output volume & $000 \mathrm{cwt}$ & 11,300 & & \\
\hline Output volume & $000 \mathrm{~kg}$ & 574,040 & $000 \mathrm{~kg}$ & $2,138,731$ \\
\hline Output value & $£ 000$ & 8,995 & & \\
\hline Industry output value & $£ 000$ & 12,315 & & \\
\hline Industry employment & 000 & 6.501 & 000 & 37.380 \\
\hline Adjusted employment & 000 & 4.748 & & \\
\hline Output per employee & $\mathrm{kg}$ & 120,901 & $\mathrm{~kg}$ & 57,216 \\
\hline
\end{tabular}

Notes: Data were first collected on quantities of sugar processed in the two countries and the volume of employment.

Comparing output per employee of $57,216 \mathrm{~kg}$ in Germany with $120,901 \mathrm{~kg}$ in the United Kingdom yields a comparative Germany/U.K. labor productivity ratio of 47.3. German data are for 1907.

Sources: United Kingdom: Board of Trade, Final Report, pp. 521-22; Germany: Kaiserliches Statistisches Amt, Statistisches Jahrbuch, vol. 30, pp. 82, 107. 


\begin{tabular}{lccccc}
\multicolumn{3}{c}{$\begin{array}{c}\text { APPENDIX TABLE 12 } \\
\text { CEMENT }\end{array}$} \\
\hline \hline & \multicolumn{2}{c}{ United Kingdom } & & \multicolumn{2}{c}{ Germany } \\
\cline { 2 - 3 } \cline { 5 - 6 } & Units & Values & & Units & Values \\
\hline Output volume & 000 tons & 2,877 & & 000 tonnes & 5,867 \\
Output value & $£ 000$ & 3,439 & & M000 & 121,917 \\
Unit value & $£$ per ton & 1.20 & & M per tonne & 20.78 \\
Industry output value & $£ 000$ & 3,735 & & M000 & 126,846 \\
Industry employment & 000 & 14.819 & & 000 & 26.356 \\
Adjusted employment & 000 & 13.645 & & 000 & 25.332 \\
Output per employee & tons & 211 & & & 232 \\
Output per employee & tonnes & 214 & & tonnes & \\
\hline
\end{tabular}

Notes: Data were first collected on quantities and values of cement produced in the two countries. Employment was adjusted in line with the ratio of the value of the output of the principal products to the total value of output in the industry.

Comparing output per employee of 232 tonnes in Germany with 214 tonnes in the United Kingdom yields a comparative Germany/U.K. labor productivity ratio of 108.1. German data are for 1910. Note that the earlier estimate of Broadberry and Fremdling, "Comparative Productivity," underestimated German employment, and hence exaggerated the German labor productivity leadership at 132.5. The lower figure reported here is to be preferred.

Sources: United Kingdom: Board of Trade, Final Report, pp. 775; Germany: Kaiserliches Statistisches Amt, "Ergebnisse," p. 68.

\begin{tabular}{lccccc}
\multicolumn{3}{c}{$\begin{array}{c}\text { APPENDIX TABLE 13 } \\
\text { SALT MINING }\end{array}$} \\
\hline \hline & \multicolumn{2}{c}{ United Kingdom } & & \multicolumn{2}{c}{ Germany } \\
\cline { 2 - 3 } \cline { 5 - 6 } & Units & Values & & Units & Values \\
\hline Output volume & 000 tons & 1,278 & & 000 tonnes & 657 \\
Output value & $£ 000$ & 650 & & M000 & 19,667 \\
Unit value & $£$ per ton & 0.51 & & M per tonne & 29.92 \\
Industry output value & $£ 000$ & 667 & & M000 & 19,729 \\
Industry employment & 000 & 4.736 & & 000 & 4.052 \\
Adjusted employment & 000 & 4.615 & & 000 & 4.039 \\
Output per employee & tons & 277 & & & 163 \\
Output per employee & tonnes & 281 & & tonnes &
\end{tabular}

Notes: Data were first collected on quantities and values of salt produced in the two countries at salt mines and brine pits and refined at salt works. Employment was adjusted in line with the ratio of the value of the output of the principal products to the total value of output in the industry.

Comparing output per employee of 163 tonnes in Germany with 281 tonnes in the United Kingdom yields a comparative Germany/U.K. labor productivity ratio of 57.8. German data are for 1908 .

Sources: United Kingdom: Board of Trade, Final Report, p. 81; Germany: Kaiserliches Statistisches Amt, "Ergebnisse," p. 42. 


\begin{tabular}{|c|c|c|c|c|}
\hline \multicolumn{5}{|c|}{$\begin{array}{c}\text { APPENDIX TABLE } 14 \\
\text { COAL MINING } \\
\end{array}$} \\
\hline & \multicolumn{2}{|c|}{ United Kingdom } & \multicolumn{2}{|c|}{ Germany } \\
\hline & Units & Values & Units & Values \\
\hline Output volume & 000 tons & 266,588 & 000 tonnes & 146,094 \\
\hline Output value & $£ 000$ & 119,553 & M000 & $1,577,174$ \\
\hline Unit value & $£$ per ton & 0.45 & M per tonne & 10.80 \\
\hline Industry output value & $£ 000$ & 122,637 & M000 & $1,577,174$ \\
\hline Industry employment & 000 & 838.586 & 000 & 562.034 \\
\hline Adjusted employment & 000 & 817.498 & 000 & 562.034 \\
\hline Output per employee & tons & 326 & & \\
\hline Output per employee & tonnes & 331 & tonnes & 260 \\
\hline Net output & $£ 000$ & 106,090 & M000 & $1,515,786$ \\
\hline Net output per employee & $£$ & 126.51 & M & 2,697 \\
\hline PPP & & & M per $£$ & 23.69 \\
\hline $\begin{array}{l}\text { Germany/U.K. net } \\
\text { output per employee }\end{array}$ & & & U.K. $=100$ & 90.0 \\
\hline
\end{tabular}

Notes: Data were first collected on quantities and values of coal mined in the two countries. Employment was adjusted in line with the ratio of the value of the output of the principal products to the total value of output in the industry.

Comparing output per employee of 260 tonnes in Germany with 331 tonnes in the United Kingdom yields a comparative Germany/U.K. labor productivity ratio of 78.5. German data are for 1908. A cross-check was carried out by comparing net output per employee in the two countries at the PPP obtained from the unit values. The results using net output are reassuringly close to the results obtained with physical indicators.

Sources: United Kingdom: Board of Trade, Final Report, pp. 66-67; Germany: Kaiserliches Statistisches Amt, "Ergebnisse," p. 2.

\begin{tabular}{|c|c|c|c|c|}
\hline & & $\begin{array}{l}\text { ENDIX TABLE } 1 \\
\text { J ORE MININ }\end{array}$ & & \\
\hline & Unit & Kingdom & & \\
\hline & Units & Values & Units & Values \\
\hline Output volume & 000 tons & 8,184 & 000 tonnes & 18,830 \\
\hline Output value & $£ 000$ & 2,328 & M000 & 84,275 \\
\hline Unit value & $£$ per ton & 0.28 & M per tonne & 4.48 \\
\hline Industry output value & $£ 000$ & 122,637 & M000 & 84,275 \\
\hline Industry employment & 000 & 838.586 & 000 & 39.594 \\
\hline Adjusted employment & 000 & 15.919 & 000 & 39.594 \\
\hline Output per employee & tons & 514 & & \\
\hline Output per employee & tonnes & 522 & tonnes & 476 \\
\hline
\end{tabular}

Notes: Data were first collected on quantities and values of iron ore mined in the two countries. Employment was adjusted in line with the ratio of the value of the output of the principal products to the total value of output in the industry.

Comparing output per employee of 476 tonnes in Germany with 522 tonnes in the United Kingdom yields a comparative Germany/U.K. labor productivity ratio of 91.0. German data are for 1908 .

Sources: United Kingdom: Board of Trade, Final Report, pp. 66-67; Germany: Kaiserliches Statistisches Amt, "Ergebnisse," p. 2. 


\section{Appendix 2: Data For Time Series Projections}

APPENDIX TABLE 16

DATA FOR TIME SERIES PROJECTIONS

\begin{tabular}{cccc}
\multicolumn{4}{c}{$(1913=100)$} \\
U.K. \\
\hline Output & $\begin{array}{c}\text { U.K. } \\
\text { Employment }\end{array}$ & German Output & $\begin{array}{c}\text { German } \\
\text { Employment }\end{array}$ \\
\cline { 3 - 4 } & & Hoffmann $\quad$ RBW & \\
\hline
\end{tabular}

\begin{tabular}{|c|c|c|c|c|c|}
\hline \multicolumn{6}{|c|}{ A. $1871-1913$} \\
\hline 1871 & 43.0 & 69.3 & 22.5 & 28.3 & 46.6 \\
\hline 1872 & 44.0 & 70.2 & 25.8 & 26.8 & \\
\hline 1873 & 45.0 & 70.5 & 26.9 & 27.6 & \\
\hline 1874 & 46.0 & 70.6 & 27.4 & 29.2 & \\
\hline 1875 & 46.0 & 70.7 & 27.2 & 29.8 & 50.4 \\
\hline 1876 & 45.5 & 70.3 & 27.6 & 31.1 & 52.0 \\
\hline 1877 & 46.5 & 70.0 & 27.2 & 30.5 & 52.1 \\
\hline 1878 & 45.5 & 69.0 & 28.1 & 33.1 & 51.7 \\
\hline 1879 & 42.9 & 66.1 & 28.4 & 34.0 & 53.3 \\
\hline 1880 & 49.8 & 70.7 & 27.6 & 32.3 & 53.8 \\
\hline 1881 & 51.7 & 72.5 & 28.9 & 33.5 & 53.8 \\
\hline 1882 & 55.0 & 74.3 & 28.8 & 32.2 & 55.3 \\
\hline 1883 & 55.4 & 75.0 & 30.9 & 35.0 & 56.5 \\
\hline 1884 & 52.7 & 71.4 & 32.3 & 37.2 & 58.4 \\
\hline 1885 & 50.2 & 71.3 & 32.8 & 38.4 & 58.5 \\
\hline 1886 & 49.8 & 71.4 & 33.4 & 40.7 & 60.3 \\
\hline 1887 & 54.5 & 74.3 & 35.4 & 41.8 & 61.7 \\
\hline 1888 & 58.3 & 77.3 & 37.2 & 42.7 & 63.7 \\
\hline 1889 & 62.5 & 80.6 & 41.0 & 46.2 & 66.4 \\
\hline 1890 & 63.0 & 83.7 & 41.4 & 46.2 & 68.7 \\
\hline 1891 & 63.6 & 81.3 & 42.3 & 46.7 & 68.4 \\
\hline 1892 & 59.5 & 79.7 & 43.3 & 48.3 & 68.1 \\
\hline 1893 & 59.4 & 82.7 & 44.9 & 51.1 & 68.3 \\
\hline 1894 & 61.4 & 80.6 & 47.5 & 55.0 & 68.9 \\
\hline 1895 & 65.2 & 82.3 & 51.3 & 58.8 & 70.9 \\
\hline 1896 & 74.2 & 84.7 & 54.0 & 60.7 & 74.4 \\
\hline 1897 & 71.2 & 86.0 & 55.3 & 60.9 & 77.3 \\
\hline 1898 & 75.3 & 87.2 & 58.6 & 63.5 & 80.0 \\
\hline 1899 & 78.3 & 88.6 & 60.2 & 63.5 & 82.0 \\
\hline 1900 & 77.4 & 88.4 & 60.1 & 62.3 & 84.0 \\
\hline 1901 & 77.1 & 88.3 & 60.1 & 61.5 & 82.7 \\
\hline 1902 & 77.4 & 88.5 & 61.3 & 62.6 & 82.4 \\
\hline 1903 & 75.5 & 88.9 & 65.5 & 69.0 & 84.1 \\
\hline 1904 & 76.0 & 88.5 & 68.2 & 73.0 & 86.3 \\
\hline 1905 & 82.6 & 90.1 & 71.2 & 75.8 & 88.5 \\
\hline 1906 & 86.5 & 92.3 & 73.8 & 76.4 & 90.9 \\
\hline 1907 & 88.8 & 93.0 & 79.2 & 80.7 & 92.6 \\
\hline 1908 & 81.2 & 89.6 & 80.1 & 82.0 & 91.2 \\
\hline 1909 & 82.2 & 90.4 & 82.0 & 84.1 & 91.2 \\
\hline 1910 & 83.1 & 94.1 & 85.2 & 87.8 & 93.9 \\
\hline 1911 & 90.2 & 96.5 & 90.4 & 93.8 & 96.3 \\
\hline 1912 & 93.9 & 97.5 & 97.2 & 98.3 & 99.0 \\
\hline 1913 & 100.0 & 100.0 & 100.0 & 100.0 & 100.0 \\
\hline
\end{tabular}


APPENDIX TABLE 16 - continued

\begin{tabular}{|c|c|c|c|c|c|}
\hline & \multirow{2}{*}{$\begin{array}{c}\text { U.K. } \\
\text { Output }\end{array}$} & \multirow{2}{*}{$\begin{array}{c}\text { U.K. } \\
\text { Employment }\end{array}$} & \multicolumn{2}{|c|}{ German Output } & \multirow{2}{*}{$\begin{array}{c}\text { German } \\
\text { Employment }\end{array}$} \\
\hline & & & Hoffmann & RBW & \\
\hline \multicolumn{6}{|c|}{ B. $1913-1938$} \\
\hline 1913 & 100.0 & 100.0 & 100.0 & 100.0 & 100.0 \\
\hline 1914 & & & & & \\
\hline 1915 & & & & & \\
\hline 1916 & & & & & \\
\hline 1917 & & & & & \\
\hline 1918 & & & & & \\
\hline 1919 & & & & & \\
\hline 1920 & & & & & \\
\hline 1921 & & & & & \\
\hline 1922 & & & & & \\
\hline 1923 & & & & & \\
\hline 1924 & & 92.9 & & & \\
\hline 1925 & 111.8 & 93.4 & 104.7 & 90.6 & 109.3 \\
\hline 1926 & 108.2 & 90.8 & 106.2 & 81.9 & 96.2 \\
\hline 1927 & 119.6 & 96.6 & 120.3 & 105.6 & 111.5 \\
\hline 1928 & 119.4 & 96.5 & 121.6 & 107.5 & 114.6 \\
\hline 1929 & 124.2 & 97.8 & 123.6 & 106.5 & 110.6 \\
\hline 1930 & 118.9 & 91.0 & 109.3 & 88.7 & 99.9 \\
\hline 1931 & 110.8 & 84.9 & 91.5 & 70.4 & 85.3 \\
\hline 1932 & 111.4 & 86.2 & 79.7 & 61.6 & 72.8 \\
\hline 1933 & 119.6 & 89.4 & 87.8 & 71.5 & 77.5 \\
\hline 1934 & 130.6 & 93.5 & 105.8 & 88.0 & 90.6 \\
\hline 1935 & 142.4 & 95.8 & 126.5 & 102.9 & 99.2 \\
\hline 1936 & 155.7 & 101.1 & 139.6 & 114.2 & 107.0 \\
\hline 1937 & 165.1 & 106.2 & 151.2 & 127.0 & 115.7 \\
\hline 1938 & 160.2 & 104.6 & 168.5 & 140.4 & 122.1 \\
\hline
\end{tabular}

Sources: United Kingdom: output and employment from Broadberry, Productivity Race, pp. 4244, based on Feinstein, National Income; Germany: Hoffmann output and employment for manufacturing only from Broadberry, Productivity Race, pp. 42-44, based on Hoffmann, Das Wachstum; RBW output from Burhop and Wolff, "Compromise Estimate," and Ritschl, "Spurious Growth," p. 216, col. 4. 


\section{Appendix 3: Comparative Productivity in Manufacturing}

APPENDIX TABLE 17

COMPARATIVE PRODUCTIVITY IN MANUFACTURING

$($ United Kingdom $=100)$

\begin{tabular}{|c|c|c|c|}
\hline & Broadberry & Burhop-Wolff-Ritschl & Burhop-Wolff-Hoffmann \\
\hline \multicolumn{4}{|c|}{ A. $1871-1913$} \\
\hline 1871 & 93.7 & 170.6 & 127.2 \\
\hline \multicolumn{4}{|l|}{1872} \\
\hline \multicolumn{4}{|l|}{1873} \\
\hline \multicolumn{4}{|l|}{1874} \\
\hline 1875 & 99.9 & 168.4 & 125.5 \\
\hline 1876 & 98.5 & 166.5 & 124.1 \\
\hline 1877 & 94.6 & 157.2 & 117.1 \\
\hline 1878 & 99.1 & 164.0 & 122.2 \\
\hline 1879 & 99.1 & 165.4 & 123.2 \\
\hline 1880 & 87.6 & 143.6 & 107.0 \\
\hline 1881 & 90.8 & 147.7 & 110.1 \\
\hline 1882 & 84.6 & 138.2 & 103.0 \\
\hline 1883 & 89.1 & 145.4 & 108.3 \\
\hline 1884 & 90.2 & 147.5 & 109.9 \\
\hline 1885 & 95.8 & 154.2 & 114.9 \\
\hline 1886 & 95.6 & 153.6 & 114.5 \\
\hline 1887 & 93.9 & 149.5 & 111.4 \\
\hline 1888 & 93.3 & 147.4 & 109.9 \\
\hline 1889 & 96.1 & 150.7 & 112.3 \\
\hline 1890 & 96.4 & 149.1 & 111.1 \\
\hline 1891 & 95.2 & 147.6 & 110.0 \\
\hline 1892 & 102.4 & 159.7 & 119.0 \\
\hline 1893 & 110.2 & 169.2 & 126.1 \\
\hline 1894 & 108.9 & 168.6 & 125.6 \\
\hline 1895 & 109.9 & 174.3 & 129.9 \\
\hline 1896 & 99.8 & 153.6 & 114.5 \\
\hline 1897 & 104.0 & 157.6 & 117.4 \\
\hline 1898 & 102.1 & 153.9 & 114.7 \\
\hline 1899 & 100.2 & 148.1 & 110.3 \\
\hline 1900 & 98.4 & 141.7 & 105.6 \\
\hline 1901 & 100.0 & 144.9 & 107.9 \\
\hline 1902 & 102.4 & 148.1 & 110.3 \\
\hline 1903 & 110.5 & 161.0 & 120.0 \\
\hline 1904 & 110.8 & 157.9 & 117.7 \\
\hline 1905 & 105.7 & 149.1 & 111.1 \\
\hline 1906 & 104.3 & 145.0 & 108.0 \\
\hline 1907 & 107.8 & 151.5 & 112.9 \\
\hline 1908 & 116.7 & 163.0 & 121.5 \\
\hline 1909 & 119.0 & 166.7 & 124.2 \\
\hline 1910 & 123.7 & 169.7 & 126.4 \\
\hline 1911 & 120.8 & 165.2 & 123.1 \\
\hline 1912 & 122.6 & 166.9 & 124.4 \\
\hline 1913 & 120.4 & 161.6 & 120.4 \\
\hline
\end{tabular}


APPENDIX TABLE 17 - continued

\begin{tabular}{lrrr}
\hline \hline & Broadberry & Burhop-Wolff-Ritschl & Burhop-Wolff-Hoffmann \\
\hline & & & \\
1925 & 96.4 & 108.9 & 96.4 \\
1926 & 11.5 & 119.0 & 11.5 \\
1927 & 104.8 & 118.0 & 104.8 \\
1928 & 103.3 & 116.9 & 103.3 \\
1929 & 106.0 & 103.0 & 106.0 \\
1930 & 100.8 & 96.0 & 100.8 \\
1931 & 99.0 & 99.1 & 99.0 \\
1932 & 102.0 & 104.2 & 102.0 \\
1933 & 101.9 & 104.9 & 101.9 \\
1934 & 100.7 & 103.2 & 100.7 \\
1935 & 103.2 & 102.0 & 102.0 \\
1936 & 102.0 & 104.1 & 101.2 \\
1937 & 101.2 & 111.2 & 108.4 \\
1938 & 108.4 & & \\
\hline
\end{tabular}

Sources: See Appendix 2; and authors' own calculations.

\section{REFERENCES}

Board of Trade. Final Report of the First Census of Production of the United Kingdom (1907). London: HMSO, 1912.

Broadberry, Stephen N. "Manufacturing and the Convergence Hypothesis: What the Long Run Data Show." This Journal 53, no. 4 (1993): 772-95.

. The Productivity Race: British Manufacturing in International Perspective, 1870-1990. Cambridge: Cambridge University Press, 1997.

. "How Did the United States and Germany Overtake Britain? A Sectoral Analysis of Comparative Productivity Levels, 1870-1990.” This JouRNAL 58, no. 2 (1998): 375-407.

"Relative Per Capita Income Levels in the United Kingdom and the United States since 1870: Reconciling Time-Series Projections and Direct Benchmark Estimates." This JOURNAL 63, no. 3 (2003): 852-63.

Broadberry, Stephen N., and Rainer Fremdling. "Comparative Productivity in British and German Industry, 1907-37." Oxford Bulletin of Economics and Statistics 52, no. 4 (1990): 403-21.

Burhop, Carsten, and Guntram B. Wolff. "A Compromise Estimate of German Net National Product, 1851-1913, and its Implications for Growth and Business Cycles." This Journal 65, no. 3 (2005): 613-57.

Chandler, Alfred D., Jr. Scale and Scope: The Dynamics of Industrial Capitalism. Cambridge, MA: Harvard University Press, 1990.

Deane, Phyllis, and William A. Cole. British Economic Growth, 1688-1959. (second edition). Cambridge: Cambridge University Press, 1969.

Dowrick, Steve, and Muhammad Akmal. "Contradictory Trends in Global Income Inequality: A Tale of Two Biases." Review of Income and Wealth 51, no. 2 (2005): 201-29.

Engel, Ernst. "Die erwerbstätigen juristischen Personen im preussischen Staate, insbesondere die Aktiengesellschaften." Zeitschrift des Königlich Preussischen Statistischen Bureaus 15 (1874): 449-536. 
Feinstein, Charles H. National Income, Expenditure and Output of the United Kingdom, 1855-1965. Cambridge: Cambridge University Press, 1972.

Fremdling, Rainer. "German National Accounts for the 19th and Early 20th Century: A Critical Assessment." Vierteljahrschrift für Sozial- und Wirtschaftsgeschichte 75, no. 3 (1988): 339-57.

. "Productivity Comparison between Great Britain and Germany, 1855-1913." Scandinavian Economic History Review 39, no. 1 (1991): 28-42.

Fremdling, Rainer, and Reiner Stäglin. "Die Industrieerhebung von 1936: Ein InputOutput Ansatz zur Rekonstruktion der volkswirtschaftliche Gesamtrechnungen für Deutschland im 19. und 20. Jahrhundert - ein Arbeitsbericht." Vierteljahrschrift für Sozial- und Wirtschaftsgeschichte 90, no. 4 (2003): 416-28.

"Eine Input-Output-Tabelle für 1936 als Grundlage einer neuen volkswirtschaftlichen Gesamtrechnung für Deutschland." Conference paper, Annual conference of the Verein für Socialpolitik, 2004.

Fremdling, Rainer, Herman de Jong, and Marcel Timmer. "British and German Manufacturing Compared: A New Benchmark for 1935/36 Based on Double Deflated Value Added." unpublished paper, University of Groningen, 2006.

Gerschenkron, Alexander. Economic Backwardness in Historical Perspective. Cambridge, MA: Harvard University Press, 1962.

Heston, Alan, Robert Summers, and Bettina Aten. "Price Structures, the Quality Factor, and Chaining." Organisation for Economic Co-operation and Development, 2001. http://www.oecd.org/dataoecd/23/40/2425050.pdf.

Hoffmann, Walther G. Das Wachstum der deutschen Wirtschaft seit der Mitte des 19. Jahrhunderts. Berlin: Springer, 1965.

Kaiserliches Statistisches Amt. Statistisches Jahrbuch für das Deutsche Reich 30 (1909).

"Berufs- und Betriebszählung vom 12. Juni 1907. Gewerbliche Betriebsstatistik." Statistik des Deutschen Reichs 213 (1910).

. "Ergebnisse der deutschen Produktionserhebungen." Vierteljahrshefte zur Statistik des Deutschen Reichs 22, no. 3 (1913), Ergänzungsheft.

"Die Ergebnisse der deutschen Produktionserhebungen." Vierteljahrshefte zur Statistik des Deutschen Reichs 23, no. 3 (1914): 108-35.

Kendrick, John W. Productivity Trends in the United States. Princeton, NJ: National Bureau of Economic Research, 1961.

Krijnse Locker, H., and M. D. Faerber. "Space and Time Comparisons of Purchasing Power Parity and Real Values." Review of Income and Wealth 30, no. 1 (1984): 53-83.

Landes, David S. The Unbound Prometheus: Technological Change and Industrial Development in Western Europe from 1750 to the Present. Cambridge: Cambridge University Press, 1969.

Maddison, Angus. Phases of Capitalist Development. Oxford: Oxford University Press, 1982.

. Dynamic Forces in Capitalist Development: A Long-Run Comparative View. Oxford: Oxford University Press, 1991.

. Monitoring the World Economy, 1820-1992. Paris: Organisation for Economic Co-operation and Development, 1995.

. The World Economy: A Millennial Perspective. Paris: Organisation for Economic Co-operation and Development, 2001.

Nuxoll, Daniel A. "Differences in Relative Prices and International Differences in Growth Rates." American Economic Review 84, no. 5 (1994): 1423-36. 
Reichsamt für wehrwirtschaftliche Planung. Die deutsche Industrie - Gesamtergebnisse der amtlichen Produktionsstatistik. Berlin: Verlag für Socialpolitik, Wirtschaft und Statistik Paul Schmidt, 1939.

Ritschl, Albrecht. "Spurious Growth in German Output Data, 1913-1938." European Review of Economic History 8, no. 2 (2004): 201-23.

Rostas, Laszlo. Comparative Productivity in British and American Industry. Cambridge: Cambridge University Press, 1948.

Summers, Robert, and Alan Heston. "A New Set of International Comparisons of Real Product and Price Levels: Estimates for 130 Countries, 1950-1985." Review of Income and Wealth 34, no. 1 (1988): 1-25.

Tooze, J. Adam. Statistics and the German State, 1900-19145: The Making of Modern Economic Knowledge. Cambridge: Cambridge University Press, 2001.

Ward, Marianne, and John Devereux. "Measuring British Decline: Direct Versus Long-Span Income Measures." This JouRnal 63, no. 3 (2003): 826-51.

Williams, Ernest E. Made in Germany. London: Heinemann, 1896. 